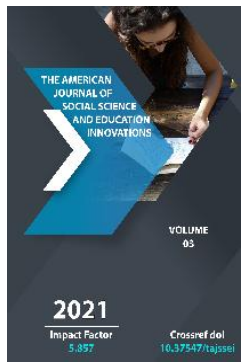

\title{
General Didactic Basis Of An Integrated Approach To The Organization Of Teaching In Higher Education Institutions
}

\author{
Toshkhonov Azizbek Tursunboevich \\ Lecturer, Namangan State University, Uzbekistan
}

Journal Website:

http://theamericanjour

nals.com/index.php/taj

ssei

Copyright: Original content from this work may be used under the terms of the creative commons attributes 4.0 licence.

\section{ABSTRACT}

This article examines the views of the authors on the descriptive features of the concept of didactic system, provides important features of the concept of didactic system.

\section{KEYWORDS}

Didactic system, pedagogical system, pedagogical-psychological concept, integration.

\section{INTRODUCTION}

The theory of teaching an elementary school teacher is a definition of a general theory of teaching and should be based on a specific general didactic system. The didactic basis of an integrative approach to the organization of primary school teacher teaching is the concept of developmental teaching.We accept the modern didactic system of higher education, supplemented by the integrative principle of teaching organization as the 
general didactic basis of the theory of teaching the primary school teacher.

There is no single definition of the term "didactic system" in the modern scientific and methodological literature 1 . In addition, the authors expressed conflicting views on the descriptive features of this concept ${ }^{2}$ or limited to examples of explicit didactic systems ${ }^{3}$.

Based on the fundamental importance of this concept, we distinguish important features of the concept of "didactic system".

V.P.Kuzmin described the system ${ }^{4}$ as "many elements (components) with integrative features and laws, forming a stable integrity and commonality."

Under the pedagogical system ${ }^{5}$, T.A.llina understands that "combined with the general

\footnotetext{
${ }^{1}$ Bespalko V.P. Foundations of the theory of pedagogical systems. Voronezh: Voronezh University Publishing House, 1997.-304 p.

Babansky Yu.K. Selected pedagogical works. -M .: Pedagogika, 1989.-560 p.

2 Pedagogy: Textbook for students of pedagogical institutions / V.A. Slastenin, I.F. Isaev and A.I. Mishchenko, E.N. Shiyanov. -M .: School-Press, 1997. p. 122-123
}

Pidkasisty P.I. Pedagogy: Textbook. 1995 p. 8384.

${ }^{3}$ Ivanov O.A. An integrative principle of building a system of special mathematical and methodological training for teachers of specialized schools. / Abstract dissertation ... doct. Ped. sciences. -M., 1997.-33 p.

4 Kuzmin V.P. Principles-consistency in the theory and methodology of K. Marx. -M., 1986. p. 111.

${ }^{5}$ Kuzmin V.P. Principles-consistency in the theory and methodology of K. Marx. -M., 1986. p. 16. purpose of action and the generality of management and separated on the basis of certain features of many regulated, interconnected elements that serve as an integral phenomenon with the environment."

V.A. Slastenin, I.F. Isaev, A.I. Mishchenko, In the textbook "Pedagogy" for students of E.N.Shiyanov pedagogical institutes, the pedagogical system is understood as "many interconnected structural elements, united by a single educational goal of personal development and acting in an integrated pedagogical process."

P.I. Pidkasistyy in the textbook "Pedagogy" as a didactic system is a set of elements that form a single integrated structure and serve to achieve the objectives of teaching. The description of the system is characterized by the description of the purposes, content, didactic methods, means, forms of teaching and its principles.

The author equates the concepts of "pedagogical-psychological concept" and didactic system, and includes in the scope of this concept the systems of J.Comenius, I.Pestalozzi, I.Gerbart, D.Dewey, G.Kershensteiner, V.Lay. In this case, the author called the systems of P.Galperin, L.Zankov, V.Davidov, K.Rojders, J.Bruner "directions" that "form a modern didactic concept." At the same time, the concept of "pedagogical system" goes beyond the narrowly understood framework of personalization (B.G .Gershunsky).

V.A.Slastenin, I.F.Isaev, A.I.Mishchenko, E.N.Shiyanov In the textbook "Pedagogy" for students of pedagogical institutes for the class "Author's pedagogical systems" Ya.A.Komensky, K.D.Ushinsky, L.N.Tolstoy, A.S.Makarenko, V.A.Sukhomlinsky, 
V.A.Karakovsky pedagogical systems are introduced. The systems of L.V.Zankov, D.B.Elkonin and V.V.Davidova, M.M.Mahmutov, P.Y.Erdniev are called "author's didactic systems".

\section{MATERIALS AND METHODS}

The category "Pedagogical system" is used to define the characteristics of the vertical section of pedagogical activity according to the level of education studied, for example, the pedagogical system of preschool education, the pedagogical system of higher education, etc. ${ }^{6}$.

An important feature in the diversity of definitions of the concept of "pedagogical system" or "didactic system" is the presence of: ideas, many interrelated elements (educational content, teaching principles, teaching methods, tools, forms) and functional side (object and environment and interaction) methods).

From a scientific point of view, the pedagogical system can be considered as a "unique pedagogical paradigm" 7 that represents a universally accepted scientific achievement, providing a model for the scientific community to identify problems and express their solutions for a certain period of time.

We understand the didactic system as a model of the pedagogical system in terms of practical application. The invariance of the

\footnotetext{
${ }^{6}$ Pedagogy: Textbook for students of pedagogical institutions / V.A. Slastenin, I.F. Isaev and A.I. Mishchenko, E.N. Shiyanov. -M .: School-Press, 1997. $-512 \mathrm{p}$.

${ }^{7}$ I. V. Koshkina Integration of subject-content information of pedagogical disciplines on a modular basis. / Diss ... Cand. ped. sciences. -Saratov, 1998. $18 \mathrm{p}$.
}

pedagogical system is complemented by specific conditions of application (definition of goals, choice of object, form of existence, etc.).

The concept of "teaching system" is a form of expression of the concept of "didactic system", for example, "developmental teaching system in primary education".

In pedagogy, the stability of paradigms is relative, because "objective social needs gradually lead to the need for periodic identification and even the replacement of individual components of the pedagogical paradigm" [10] (goals, methods of interaction).

At the same time, the change of specific systems of education as the realization of subjective and objective social needs is primary. The education system is a formative factor of pedagogical interaction "in order to solve educational problems, aimed at meeting the needs of society and the needs of the individual in development and selfdevelopment" [10, p. 84], i.e. defines the learning process.

There are two components of the pedagogical process: the content of education and teaching aids, which include pedagogical forms, methods, techniques. The content and means of education are necessary and sufficient for the emergence of a voluntary pedagogical system [10].

The separation of the complex approach in pedagogical theory and its transformation into an independent pedagogical problem has been developed in the works of advanced educators of different periods A.Ya.Comenius, I.G. Pestalotstsi, A. Disterveg, K.D.Ushinsky and others. They approached 
the problem from different angles, but for each was unique in that students sought to provide a system of knowledge about the universe.

In the study of the structure of science, K.D.Ushinsky noted that "in addition to specific concepts that apply to each science individually, there are many concepts, some of which are common to all sciences" [12, p. $600]$.

An important stage in the formation of the knowledge system (educational function) and the study of a unified approach to education in terms of the foundations of the scientific worldview (educational function) was the work of B.G. Ananev and Sh.I. Ganelin is a researcher in the 50s. The main focus of the research was on ways to consistently implement the interactions between leading ideas and related course concepts (the outside of integration).

Yu.K.Babansky, V.V.Davydov, L.V.Zankov, I.F.Isaev, G.M.Kodjaspirova, V.M.Maksimova, N.A.Menzhinskaya, A.I.Mi of the theory of integrated teaching The further development is expressed in the works of Shchenko, M.N.Skatkin, V.A.Slastenin, G.F.Fedorets, E.N. Shiyanov, D.B. Elkonin and others.

The rules of evolving theories are based on the idea of the structure of the didactic interconnected teaching, upbringing and development process. The study of integration processes in teaching has been conducted mainly in two directions.

The first direction defined the existence of interdisciplinary relations, their defining role in the formation of worldviews of knowledge (P.G. Kulagin, V.N.Maksimova, G.F. Fedorets
[8; 9; 13]). G.F. Fedorets proposed to classify interdisciplinary relations as follows:

- By composition - objects, facts, concepts, theories, methods;

- By method - logical and methodological methods of the educational process;

- Orientation - the formation of general skills and competencies for the definition of educational tasks.

Subsequent studies based on the study of the internal relations of science have provided definitions. For example, V.A.Dalinger [3] divided relations into: by content - meaningful, operational, methodical, organizational; by method - chronological, chronometric; in the direction - multi-sided, two-sided, one-sided.

The main content of these classifications is based only on the separation of noninformative "leading concepts". They serve the purposes of deeper understanding and learning [3, p. 21]. The need to separate the "target knowledge" group as the basis of integrative processes in relation to the process of training a future teacher in a vocational school is described in [4].

It should be noted that in the process of teaching, in the diversity of interdisciplinary and internal connections of science, they reflect the "static" nature of the description of integration.

As a second direction in the study of the integrative nature of teaching, the leading ideas of a worldview in the organization of the teaching process (M.N.Skatkin, V.V.Davidov, L.V.Zankov, etc.) and, above all, the work of LSVygotsky teaching ideas can be separated. The essence of educational activity is expressed in the assimilation of objective products of social experience (V.V.Davidov, 
I.Ya.Lerner, AKMarkov and others). In the process of educational activity based on the method of scientific knowledge, the ideas of the worldview are enriched with theories, concepts, evidence and form a holistic scientific system of knowledge about nature and society.

\section{RESULT AND DISCUSSION}

The concept of developmental learning as a teaching of a certain type of thinking activity is reflected in the didactic principles of developmental learning: teaching at a high level of difficulty, the principle of the leading role of theoretical knowledge, fast learning, understanding the learning process, etc. (L.V.Zankov).

The integrative nature of developmental learning is expressed in the invariant nature of cognitive activity. This direction of integration is the basis for building a system of training primary school teachers according to the specifics of the teaching process and the characteristics of professional activity at the faculty.

When it comes to the didactic basis of integrated teaching, the principle of integrated reflection of science in the general context of theory and method, in the system of relations of science with other forms of social consciousness and practice (MN Skatkin, V.V. Kraevsky, I.Ya.Lerner and others) it is important to note that the network of human activities reveals the essence of the concept of educational science as a whole of knowledge, methods and relationships that are formed in the process of studying science.

\section{CONCLUSION}

The study of the model of educational science as a generalized model of knowledge based on the function of information in the process of human education (GS Sukhobskaya, Yu.A. Sherkovin, V.Ya. Yadov, etc.) allows to distinguish three components: epistemic, instrumental, motivational-assessment, each of which can be the basis of integration. According to a number of studies, the content of education is a model of the subject area of science (Yu.K.Babansky, V.P.Bespalko, B.C.Lednev).

The principles and design methods underlying the construction of models can serve as an objective basis for integration, distinguishing the class of subject tasks appropriate to this level of abstraction.

Based on the above, the current state of development of pedagogy as a science allows for the implementation of integrative teaching within the didactic systems of higher education on the basis of various systems.

\section{REFERENCES}

1. Babansky Yu.K. Selected pedagogical works. -M .: Pedagogika, 1989.-560 p.

2. Bespalko V.P. Foundations of the theory of pedagogical systems. Voronezh: Voronezh University Publishing House, 1997.-304 p.

3. Dalinger V.A. Intra-subject communications as a methodological basis for improving the process of teaching mathematics at school: Abstract of a thesis. ... Dr. ped. nauk.-SPb., 1992.-52 p.

4. Dorofeev G.V. On the principles of selection of the content of mathematical 
education // Mathematics in school, 1990, issue 6. -FROM. 2-5.

5. Ivanov O.A. An integrative principle of building a system of special mathematical and methodological training for teachers of specialized schools. / Abstract dissertation ... doct. Ped. sciences. -M., 1997.-33 p.

6. I. V. Koshkina Integration of subjectcontent information of pedagogical disciplines on a modular basis. / Diss ... Cand. ped. sciences. -Saratov, 1998.-144 p.

7. Kuzmin V.P. Principles-consistency in the theory and methodology of K. Marx. -M., 1986. $-460 \mathrm{p}$.

8. Kulagin P.G. Interdisciplinary communication in the learning process. M .: Education, 1981.-14 p.

9. Maksimova V.N. Interdisciplinary communication in the learning process. M .: Enlightenment. 1988.-191 p.

10. Pedagogy: Textbook for students of pedagogical institutions / V.A. Slastenin, I.F. Isaev and A.I. Mishchenko, E.N. Shiyanov. -M .: School-Press, 1997. -512 p.

11. Pidkasisty P.I. Pedagogy: Ўқuv қy̆llanma Textbook. 1995.-680 p.

12. Ursul A.D. Integrative and general scientific tendencies of knowledge and philosophy // Problems of Philosophy. 1977. -No. 1. -P. 114-124.

13. Fedorets G.F. Interdisciplinary connections between pedagogy and psychology. - $\mathrm{L} \quad$ : Publishing house Leningrad. Ped. in-ta, 1988. -87 p.

14. Ilyina T.A. Systemic and structural approach to the organization of training. M., $1972.220 \mathrm{p}$.

15. Abdullayev K. A. Using technologies of subjects'integration in teaching uzbek classic literature //Theoretical \& Applied Science. - 2019. - №. 12. - C. 278-280.
16. Abdullaev K. A. Using historical, scientific and artistic works in learning the personality of alishernavoi //Scientific Bulletin of Namangan State University. 2020. - T. 2. - №. 6. - C. 231-235.

17. Sulaymonov M. Y. Studying the creativity of hafiz khorezmi based on the biographical method //Scientific Bulletin of Namangan State University. - 2019. - T. 1. - №. 4. - C. 190-196.

18. Shermatova M. R. Work On Teaching Classical Literature To Primary School Students //The American Journal of Social Science and Education Innovations. 2021. - T. 3. - №. 04. - C. 600-605. 